\title{
DAMPAK KONFLIK INTERNAL KEPEMIMPINAN PADA KINERJA DOSEN PERGURUAN TINGGI ISLAM
}

\author{
Adri Efferi \\ Sekolah Tinggi Agama Islam Negeri (STAIN) Kudus \\ Jl. Conge Ngembal Rejo-Jawa Tengah \\ Email: Adri_efferi@yahoo.co.id
}

\begin{abstract}
ABSTRAK
Tulisan ini bermaksud mengurai benang kusut konflik internal kepemimpinan yang secara umum hampir terjadi di seluruh perguruan tinggi Islam negeri di Indonesia, terutama yang lembaganya masih berstatus institut (IAIN) dan sekolah tinggi (STAIN). Persoalan tersebut diungkap melalui metode studi kasus. Kasus yang dipilih adalah kasus STAIN Kudus di Jawa Tengah. Data dikumpulkan melalui wawancara, pengamatan dan studi dokumentasi serta dianalisis dengan menggunakan model interaktif Miles dan Huberman yang dilandasi oleh teori kepemimpinan transaksional dari Yulk (1998), teori kepemimpinan efektif dari Razik (1995) dan model kepemimpinan (Muhammad SAW) Islam. Hasil penelitian menunjukkan bahwa konflik internal kepemimpinan yang terjadi di STAIN Kudus merupakan dampak dari mekanisme 'pemilihan langsung' ketua pada tahun 2005 akhir. Perseteruan antara kubu yang menang dan kalah berlanjut menjadi konflik internal kepemimpinan yang berkepanjangan. Konflik tersebut ternyata berdampak pada menurunnya kinerja dosen. Hal ini ditandai dengan bergesernya fokus kinerja dosen dari kinerja yang semestinya akademik menjadi kinerja yang bermuatan politis.
\end{abstract}

Kata Kunci : Kepemimpinan, Kinerja Perguruan Tinggi Islam

\section{ABSTRACT}

This paper intends to unravel the leadership internal conflict that generally happened in all State Islamic College in Indonesia, especially in the institutions named Institute (LAIN) and high school (STAIN). These issues was revealed by using case study. The selected case is STAIN Kudus in Central Java. Data were collected through interviews, observation and documentation study. The data was then analyzed using Miles and Huberman interactive model and based on the theory of transactional leadership proposed by Yulk (1998), the theory of effective leadership from Razik (1995) and models of leadership (Mubammad SAW) of Islam. The results showed that internal leadership conflicts that occurred in STAIN Kudus is the impact of 'direct election' mechanism in selecting the chairman in the late 2005. The battle between the winning and losing camps continues to become a long-drawn leadership internal conflicts. The conflicts apparently decrease the performance of the lecturers. It is characterized by shifting the focus of the lecturers's performances from academic to political performance.

Keyword: Leadership, Performance Islamic University 


\section{PENDAHULUAN}

Pengelolaan pendidikan mulai dari tingkat yang paling dasar sampai ke perguruan tinggi hendaknya mendapat perhatian yang serius dari semua pihak, khususnya pemerintah (Kuncoro, 2008: 3). Rata-rata perguruan tinggi di Indonesia belum memiliki kemampuan daya saing 'competitive comparative' bila dibanding dengan perguruan tinggi di luar negeri. Pada bulan Juli 2010 Webometrics telah mengumumkan daftar universitas terbaik dari berbagai negara di Asia Tenggara. Dari daftar tersebut, Institut Teknologi Bandung (ITB) di Indonesia, menduduki peringkat pertama namun menduduki peringkat ke-8 di Asia Tenggara. Universitas Gadjah Mada (UGM) menduduki peringkat kedua di Indonesia dan hanya menduduki peringkat ke-10 di Asia Tenggara (http://www.webometrics.info).

Salah satu indikator keberhasilan sebuah perguruan tinggi adalah tingginya kualitas kinerja sumber daya manusia yang dimiliki oleh lembaga tersebut, terutama dosen. Jika kinerja dosen baik, dua pertiga kualitas perguruan tinggi pun akan menjadi baik. Salah satu faktor yang menentukan berkualitasnya kinerja dosen di sebuah perguruan tinggi adalah faktor kualitas pimpinan dan pola kepemimpinan yang dijalankan. Berarti rektor, direktur, atau ketua suatu perguruan tinggi, baik sebagai personnal, educator, manager, administrator, supervisor, social, leader, entreupreneur and climator sangat berperan dalam membentuk kualitas dosen (Usman, 2006: 277).

Dalam konteks manajemen, Sutermeister menegaskan bahwa kualitas pemimpin merupakan salah satu faktor yang dapat mempengaruhi kinerja personil perusahaan, di samping latihan, pengalaman, pendidikan, sikap kepribadian, organisasi, kondisi sosial, kebutuhan individu, kondisi fisik tempat kerja, kemampuan dan motivasi kerja (Sutermeister, 1976: 1). Covey menekankan bahwa seorang pemimpin yang baik ditandai dengan berlakunya empat peran kepemimpinan yang ada di dalam dirinya (the 3 roles of leadership), yakni sebagai perintis 'pathfinding', penyelaras 'aligning' dan pemberdaya 'empowering' (Covey dalam Hesselbein at. al, 1996: 152-153). Adapun faktorfaktor yang dapat mempengaruhi kualitas pemimpin ada dua yaitu faktor internal dan faktor eksternal. Faktor internal di antaranya berupa struktur, aturan dan praktik-praktik yang dapat mendukung atau membatasi kemampuan pemimpin dalam menjalankan tugasnya. Faktor internal mencerminkan kemampuan individu dalam memusatkan perhatian dirinya sebagai pemimpin dengan cara mempertimbangkan kualitas atau kemampuan yang dimilikinya. Faktor eksternal di antaranya dapat berupa lingkungan ekonomi, sosial dan politik. Jabatan atau posisi yang ditempati seorang pemimpin menggambarkan perilaku yang mengindahkan, menyadari, atau menolak suatu keadaan tempat dia berada (Jillson and Wilson, 1994: 73).

Beberapa abad yang lalu, seseorang dikatakan memiliki kualitas pribadi ketika ia dilahirkan sebagai raja atau bangsawan. Di era modern, keunggulan seorang pemimpin didasarkan pada beberapa kelebihan yang tidak dimiliki orang 
lain dalam kelompoknya, seperti kecerdasan, tingkat pendidikan, bertanggung jawab, aktivitas dan partisipasi sosial serta status ekonomi dan sosial. Hal tersebut nampak jelas pada lembaga atau organisasi formal, yang telah menerapkan standar atau aturan yang baku tentang syarat-syarat menjadi seorang pemimpin. Dalam Islam, potensi setiap individu ini dikenal istilah fitrah, yaitu sifat tertentu yang ada 'maujud' sejak masa awal penciptaannya atau disebut juga sifat pembawaan manusia yang ada sejak manusia dilahirkan. Beberapa fitrah yang dimiliki oleh manusia antara lain: fitrah bermoral, fitrah kemerdekaan, fitrah kebenaran, fitrah individu, fitrah sosial, fitrah politik, fitrah seni dan fitrah-fitrah lainnya. Berbagai fitrah tersebut harus dikembangkan sehingga terwujud dalam perilaku-perilaku positif dalam kehidupan sehari-hari (Muhaimin, 2002: 16-19). Faktor ini pun termasuk ke dalam faktor internal kepemimpinan.

Gaya memerintah seorang perwira tertinggi, berbeda dengan gaya memerintah seorang rektor. Hal ini terkait dengan aturan dan norma yang diberlakukan di masing-masing organisasi. Seorang pemimpin pada dasarnya tidak pernah bekerja dalam ruang vakum, tetapi dia selalu ada dalam lingkungan sosial yang dinamis. Situasi dan kondisi khusus selalu membutuhkan tipe kepemimpinan yang khusus pula. Seorang pemimpin dalam hal ini harus memiliki fleksibilitas yang tinggi terhadap situasi dan kondisi yang menyertai para bawahannya. Bila tidak, maka yang akan muncul bukan kepatuhan 'komitmen' melainkan perlawanan 'resistensi' dari para bawahan yang pada akhirnya berakibat pada tidak efektifnya suatu kepemimpinan. Pemahaman terhadap situasi dan kondisi ini sangat penting bagi seorang pemimpin sehingga gaya atau model kepemimpinannya tidak monoton. Dua hal ini mencerminkan faktor eksternal kepemimpinan.

Suksesi di Sekolah Tinggi Agama Islam (STAIN) Kudus meniscayakan adanya sejumlah faktor baik internal maupun eksternal kepemimpinan perguruan tinggi tersebut yang berdampak pada kinerja dosen. Sepanjang perjalanan sejarah, proses pengangkatan Ketua STAIN Kudus kerap kali berlangsung dalam situasi yang kental dengan nuansa politis, penuh konflik dan penuh intrik. Nuansa euphoria tuntutan pemilihan presiden secara langsung untuk tahun 2006 berdampak pada demokratisasi kampus (hasil pengolahan data dari berbagai sumber).

Pada akhir masa kepemimpinan Muslim A. Kadir (2005), tuntutan pemilihan ketua secara langsung pun sangat gencar diajukan oleh sivitas kampus. Akhirnya, Masyharuddin dikukuhkan sebagai ketua STAIN Kudus yang pertama dan terakhir kali dipilih secara langsung oleh dosen. Mekanisme pemilihan langsung ketua STAIN Kudus sempat menimbulkan harapan baru di kalangan sivitas akademika, terutama dosen, yakni terbukanya kebebasan dalam memenuhi hak-hak seperti berekspresi maupun mengembangkan karir (kenaikan pangkat dan studi lanjut ke jenjang yang lebih tinggi). Namun dampak psikologis dari pemilihan langsung pimpinan STAIN Kudus periode sebelumnya masih terasa. Kubu yang kalah masih menyimpan perasaan 'dendam yang cukup mendalam' 
atas kekalahannya. Akibatnya, pelaksanaan roda kepemimpinan ketua baru STAIN Kudus terpilih, Masyharuddin cukup terganggu, sebab ada kubu oposisi yang dirasakan oleh mereka sebagai ancaman. Pada pertengahan tahun 2008, Masyharuddin mengalami sakit keras, sehingga dia tidak bisa menjalankan tugasnya selama kurang lebih satu tahun pada masa jabatannya. Akhirnya, pada pertengahan tahun 2009 beliau meninggal dunia. STAIN Kudus kemudian dipimpin oleh pejabat sementara dari Jakarta. Hal ini karena pihak Departemen Agama di Jakarta mengetahui bahwa ada indikasi munculnya kembali perbedaan pandangan politis sebagai dampak dari pemilihan langsung ketua sebelumnya. Pejabat sementara tersebut ditugasi menyelesaikan dua hal yaitu membereskan sistem administrasi lembaga dan membangun suasana yang normal kembali agar STAIN Kudus mampu melaksanakan suksesi kepemimpinan secara aman, nyaman dan prosedural. Pihak Departemen Agama Pusat berharap bahwa kelak, ketua terpilih yang sesungguhnya dapat diterima oleh semua pihak. Mekanisme pemilihan ketua STAIN Kudus secara langsung kemudian diubah kembali melalui pemilihan yang diwakili oleh senat STAIN Kudus. Untuk menghindari perseteruan antarkubu, para calon ketua yang dianggap memenuhi syarat harus asli berasal dari kalangan STAIN Kudus dan tidak diperkenankan mendaftar secara langsung. Ternyata yang terpilih menjadi Ketua STAIN Kudus periode 2009-2013 adalah Abdul Hadi dari Institut Agama Islam Negeri (IAIN) Wali Sanga Semarang yang sebelumnya juga pernah menjabat sebagai Ketua STAIN di Samarinda, Kalimantan Timur (studi dokumentasi dan hasil wawancara).

Ketua baru yang ternyata bukan putera asli Kudus sejak masa awal kepemimpinannya mendapat banyak tantangan. Setiap kebijakan yang dibuatnya senantiasa mendatangkan pro dan kontra, dari dua kubu yang mendukung dan menolak ketua STAIN sebelumnya, Masyharuddin. Akhirnya, beliau, Abdul Hadi, memutuskan untuk 'merapat' dengan salah satu kubu sehingga muncul sejumlah kesepakatan yang saling menguntungkan antara ketua terpilih, Abdul Hadi dengan salah satu kubu tersebut. Dampaknya, kebijakan dalam rangka meningkatkan kinerja dosen cenderung dimaknai oleh lawannya sebagai langkahlangkah politis yang hanya menguntungkan satu pihak saja dan merugikan pihak yang dipandang tidak sejalan dengan kebijakan pimpinan. Setiap kegiatan pengembangan akademik yang dilaksanakan, seperti pemberian bantuan studi lanjut bagi yang sedang menempuh jenjang S3, pembagian dana penelitian dan pembuatan jurnal senantiasa ditafsirkan politis daripada akademis. Kelompok yang tidak puas pun sering menginformasikan hal-hal yang bersifat negatif kepada pihak Kementerian Agama Pusat RI tentang kepemimpinan di STAIN Kudus. Hal ini menyebabkan konsentrasi pimpinan STAIN Kudus terpilih menjadi terpecah. Di satu sisi, pimpinan ingin memajukan lembaga, tapi di sisi lain harus mengatasi provokasi-provokasi yang cenderung menjatuhkan citra lembaga STAIN Kudus (studi dokumentasi dan hasil wawancara).

Penelitian ini bertujuan untuk mendeskripsikan, membahas dan menganalisis sejumlah faktor internal dan eksternal yang mempengaruhi 
kepemimpinan STAIN Kudus yang berdampak pada konflik internal kepemimpinan di lembaga mereka yang pada akhirnya berdampak pula pada kualitas kinerja dosen. Penelitian ini berupa penelitian lapangan (field research) dan bersifat kualitatif-deskriptif. Metode penelitian kualitatif yang dipilih adalah studi kasus dengan tujuan agar persoalan penelitian dapat didekati secara mendalam dan alamiah. Metode mengumpulkan data dilakukan melalui wawancara, observasi dan studi dokumentasi. Uji keabsahan data dilakukan dengan cara menguji credibility 'validitas internal', transferability 'validitas eksternal', dependability 'reliabilitas' dan confirmability 'objektivitas'. Analisis data dilakukan dengan cara menyederhanakan, mengorganisasikan dan menjabarkan data ke dalam unitunit/kategori sesuai dengan fokus masalah. Setelah itu data ditelaah secara mendalam, disintesakan dan dibuat ke dalam simpulan. Secara umum, analisis data yang digunakan dalam penelitian ini mengacu pada analisis data model Miles and Huberman (1994) yang secara interaktif dilakukan melalui tiga tahap yakni reduksi data 'data reduction', penyajian data 'data display' dan verifikasi/penarikan kesimpulan 'verification/conclution drawing'.

\section{PEMBAHASAN}

\section{Temuan Penelitian}

Berhubungan dengan sumber daya dosen, pada tahun 2012, Sekolah Tinggi Agama Islam Negeri (STAIN) Kudus mempunyai 90 orang dosen tetap yang berkualifikasi S2 dan S3 serta hanya ada tiga orang dosen yang masih bergelar S1 (itu pun dalam taraf penyelesaian S2). Umumnya, mereka yang masih berkualifikasi S1 itu karena saat mereka mendaftar menjadi dosen, belum dipersyaratkan berijazah S2. Akan tetapi untuk pengangkatan sekarang (2012), semua program studi sudah mempersyaratkan bahwa calon dosen minimal berkualifikasi S2. Jumlah total mahasiswa dari 4 jurusan yang dimiliki STAIN Kudus kurang lebih 3000 orang. Berarti perbadingan rasio dosen dengan mahasiswa adalah, 1 orang dosen berbanding dengan 33,3 mahasiswa. Perbandingan ini mendekati ideal bahkan menjadi ideal ketika ditambah dengan dosen honorer yang jumlahnya tidak terdata dengan jelas. Akan tetapi karena tugas pokok dan fungsi dosen tetap dengan dosen honorer agak berbeda maka peran dosen honorer belum semaksimal peran dosen tetap sehingga tidak dikalkulasikan sebagai perbandingan (Data Kepegawaian STAIN Kudus, 2012).

Kinerja dosen Sekolah Tinggi Agama Islam Negeri (STAIN) Kudus menunjukkan bahwa: 1) tingkat kehadiran dosen dalam memberi materi perkuliahan di ruang kelas hanya $75 \%$. Artinya dari 14 kali tatap muka yang ditetapkan, rata-rata hanya bisa dilaksanakan 8 sampai 10 kali saja; 2) penelitian yang dilakukan oleh dosen cenderung hanya bersifat formalitas dan cenderung hanya mengejar kuantitas, belum menyentuh aspek kualitas. Selama kurun 3 tahun terakhir jumlah penelitian dosen yang didanai oleh lembaga hanya 130 orang. Hasil-hasil penelitiannya juga belum dipublikasikan dengan terencana dan 
berkelanjutan. Sejak tahun 2004 sampai dengan 2009 tercatat ada 103 judul buku daras berbanding 77 orang dosen tetap. Berarti rata-rata pertahunnya hanya 17 judul buku daras berbanding 77 dosen tetap. Jika satu orang dosen menulis buku 1 saja berarti ada 60 orang dosen selama kurun waktu 6 tahun tidak pernah menulis buku; 3) kegiatan pengabdian kepada masyarakat masih didominasi ceramah-ceramah keagamaan, baik yang bersifat rutin maupun insidental (peringatan hari-hari besar/raya Islam) (Dokumen Lembaga PPMP STAIN Kudus, 2010). Dengan demikian, antara rasio jumlah dosen dengan jumlah mahasiswa yang hampir ideal itu, ketika dihubungkan dengan kinerja dosen berbanding terbalik. Artinya, meskipun rasio jumlah dosen dengan mahasiswa mendekati ideal namun tidak berdampak pada peningkatan kualitas kinerja dosen dalam melayani mahasiswa. Berarti, ada faktor lain yang mempengaruhi rendahnya kinerja dosen. Berdasarkan sejumlah pengamatan dan wawancara yang dilakukan, salah satu faktor tersebut adalah faktor konflik internal pemimpin dan kepemimpinan yang terjadi di STAIN Kudus.

Opini-opini negatif dan provokatif tentang STAIN Kudus yang sampai ke Kementerian Agama (Kemenag) Pusat di Jakarta berdampak pada pola pikir orang-orang Kemenag di Jakarta. Ungkapan-ungkapan seperti bahwa pimpinan STAIN Kudus cenderung hanya mengakomodasi kepentingan satu kelompok dibanding dengan kelompok lainnya lebih dimaknai secara politis daripada akademis. Pimpinan dari Jakarta pun turun tangan dan menyampaikan hal tersebut dalam berbagai forum yang diselenggarakan oleh STAIN Kudus. Halhal yang disampaikan 'orang-orang Jakarta' ditanggapi jajaran pimpinan STAIN Kudus sebagai hal yang negatif karena cenderung menuduh dan memojokkan. Akhirnya beberapa jajaran pimpinan STAIN Kudus mengambil sikap bahwa ketika tidak ada hal yang sangat penting dan mendesak mereka lebih memilih tidak menghadiri forum-forum yang digagas oleh Kemenag Pusat. Lambat laun sikap jajaran pimpinan tersebut berdampak pada menurunnya tingkat kepercayaan umum sivitas akademika STAIN Kudus terhadap kualitas kepemimpinan dari pimpinannya. Sivitas akademika STAIN Kudus mulai menganggap bahwa para pejabat STAIN Kudus tidak profesional. Kinerja dosen pun terpengaruh. Mereka mulai kurang mempedulikan kegiatan akademis seperti kurang seriusnya para dosen dalam mengajar.

Melihat situasi yang kurang kondusif tersebut, dalam rangka menjalankan dan mengamankan roda kepemimpinannya, Ketua STAIN Kudus dan beberapa jajarannya berupaya membuat kesepakatan-kesepakatan tertentu dengan pihakpihak yang dalam penilaian pimpinan bisa menjamin kelangsungan kepemimpinannya. Upaya Abdul Hadi selaku pimpinan STAIN Kudus tersebut dimaknai oleh kubu oposisi sebagai pimpinan yang lebih memilih menjalankan pola kepemimpinan transaksional. Dalam pandangan kubu oposisi, pola ini akan senantiasa menempatkan hal-hal yang bersifat finansial menjadi komoditi utama dalam upaya mendapat dukungan dan loyalitas bawahan. Loyalitas bawahan terhadap atasan pun kemudian diukur dari besarnya keuntungan pribadi yang 
akan mereka peroleh dari atasan. Kondisi tersebut tercermin dalam pernyataan dosen X, sebagai kubu oposisi (nama disamarkan sesuai dengan permintaan informan) yang mengatakan:

"Pemimpin STAIN Kudus saat ini kurang bisa berlaku adil. Ada keberpihakan yang terlalu dominan kepada kelompok yang telah menyukseskan beliau menjadi ketua. Hal ini nampak dari misalnya distribusi penunjukan pembimbingan skripsi, penguji baik untuk menguji proposal maupun menguji skripsi 'munaqasyah' dan dosen pembimbing untuk kegiatan praktikum yang cenderung memberi porsi lebih besar kepada para pendukung mereka agar mereka tetap mendukung pimpinan" (hasil wawancara dengan salah seorang dosen pada tgl. 10-02-2010, Pkl. 12.00-13.00).

Dalam pandangan kubu oposisi, sebagai dampak dari konflik internal pasca pemilihan ketua sebelumnya yang berlarut-larut itu, pimpinan pun mengambil keputusan bahwa ia, di samping harus menerapkan pola kepemimpinan transaksional juga harus menjalankan beberapa fungsi kepemimpinannya secara tertutup. Hal ini dilakukan agar keberpihakan yang dia lakukan tidak jatuh ke kubu yang menentangnya. Ironisnya, ketidakterbukaan tersebut justru diketahui secara terbuka setelah ada indikasi kecolongan dalam pembagian dana penelitian kepada dosen. Ternyata, ada beberapa dosen dari kubu oposisi yang mendapatkan dana penelitian, tetapi mereka merasa bahwa dana yang mereka terima tidak sama dengan dosen lain yang merupakan bagian dari kubu pendukung sang ketua. Akhirnya, kelompok kubu oposisi yang merasa dirugikan itu tidak mau melindungi dan mengamankan ketidakterbukaan pimpinan, bahkan mereka kemudian memublikasikannya. Namun, menurut dosen $\mathrm{Y}$, sebagai kubu pendukung ketua (nama minta disamarkan dengan alasan takut dituduh memfitnah) mengemukakan pembelaannya:

"Sebetulnya, para pimpinan STAIN Kudus yang sekarang ini, sudah menjalankan tugas sebagaimana mestinya. Mulai dari ketua hingga ketua jurusan dan ketua program studi, mereka telah menunaikan tugasnya dengan baik. Lihat saja, sarana dan prasarana kampus terus bertambah, bahkan perkembangannya cukup pesat. Gedung-gedung perkuliahan, ruang praktikum, asrama dan aula semakin hari semakin lengkap dan semakin bagus. Kesempatan bagi dosen dan karyawan untuk melanjutkan studi lanjut ke jenjang yang lebih tinggi, baik ke jenjang magister maupun doktor semakin terbuka lebar. Proses kenaikan pangkat pun tidak berbelitbelit. Di samping itu, dalam hal komunikasi, beliau, ketua STAIN sangat komunikatif dan pendekatan yang dipakai tidak selalu resmi, sering menggunakan pendekatan personal bahkan informal. Hal ini sangat terasa saat beliau, ketua STAIN memimpin rapat. Sering sekali, di tengah-tengah situasi rapat yang serius, beliau melontarkan guyonan (bercanda). Dalam pandangannya (ketua STAIN), tidak mesti, semua persoalan itu dihadapi dengan serius, tetapi dengan santai dan jenaka agar tidak jenuh" (hasil wawancara dengan dosen tgl. 10-02-2010, Pkl. 12.00-13.00). 
Perbedaan pendapat di antara dosen telah menunjukkan bahwa konflik internal pimpinan di STAIN Kudus telah mempengaruhi perilaku dosen dalam menyikapi kebijakan-kebijakan pimpinan. Secara umum, sikap dosen terbagi ke dalam dua kubu, yaitu kubu yang mendukung pimpinan dan kubu yang menentang pimpinan.

Berawal dari persoalan ketidakterbukaan tentang dana penelitian itu, kubu oposisi akhirnya memunculkan mosi tidak percaya atas kepemimpinan Ketua. Ketua dianggap telah berlaku tidak adil dalam menjalankan kepemimpinannya dan dituduh hanya memihak kelompok dosen yang senantiasa loyal pada kepemimpinannya. Dalam pandangan mereka, persoalan ini dianggap sebagai pelecehan terhadap institusi STAIN sendiri apalagi ia merupakan figur kiai. Sebagai institusi perguruan tinggi keagamaan (Islam), yang seharusnya menjunjung tinggi nilai-nilai Islami, justru pimpinan menampilkan praktik kepemimpinan yang tidak Islami. Dalam pandangan mereka, sangat tidak masuk akal, seorang pimpinan perguruan tinggi Islam menjalankan praktik kepemimpinan yang tidak amanah.

Terpilihnya Abdul Hadi sebagai Ketua STAIN Kudus, pada awalnya diharapkan dapat menampilkan sosok pemimpin yang kharismatik. Abdul Hadi adalah Pengasuh Pondok Pesantren terbesar di Jawa Tengah, yakni Pondok Pesantren Futuhiyyah yang terletak di Desa Mranggen, Kabupaten Demak Propinsi Jawa Tengah. Dalam hemat sivitas akademika STAIN Kudus, Kiai atau pimpinan pondok pesantren dikenal lazim menerapkan pola kepemimpinan kharismatik. Harapannya, pimpinan kharismatik ini mampu bersinergi dengan mayoritas sivitas akademika STAIN Kudus yang berasal dari atau pernah mengenyam pendidikan di pondok pesantren. Sivitas akademika STAIN Kudus sepertinya menyepakati bahwa sosok yang kharismatik itu, dapat menyelesaikan persoalan-persoalan kampus terutama politik kepemimpinan kampus. Figur Ketua STAIN yang berbasis pesantren dan seorang kiai, dipandang sebagai orang yang paling tepat untuk mengembalikan kondisi kampus.

Harapan mereka ternyata tidak sesuai dengan kenyataan. Ketua terpilih cenderung memposisikan dirinya sebagai figur yang anti kritik, membuat dosen kurang nyaman ketika bertemu apalagi saat hendak bertukar pikiran dengan beliau. Iklim yang terbangun jauh dari budaya dialogis. Sivitas akademika tidak ditempatkan pada posisi layaknya seorang ilmuwan yang mengakui bahwa masing-masing ilmuwan punya kesempatan yang sama untuk mengeluarkan pendapat dan pemikirannya. Kahar Utsman, selaku Pembantu Ketua I (bidang akademik) STAIN Kudus berujar:

"Ya begitulah resikonya kalau kita punya pimpinan Kiai. Jadi jangan salahkan siapa-siapa kalau beliau (Ketua STAIN Kudus terpilih/Abdul Hadi) lebih betah di ruangannya, ketimbang keliling mengamati situasi kampus. Kalau kita butuh atau perlu sesuatu, silahkan datang sendiri ke ruangan beliau”.

Kemudian ia menambahkan: 
"Terkadang keputusan yang ditetapkan pimpinan tidak ada artinya, karena kemampuan mewujudkan atau menterjemahkan instruksi/perintah, yang seringkali masih bersifat global. Di samping itu fungsi pengawasan dari pimpinan tidak berjalan baik, terbukti perintah-perintah yang keluar hanya sebatas instruksi sesaat, sejauh mana instruksi itu dilaksanakan, pimpinan tidak melakukan pemantauan" (hasil wawancara dengan Puket I tgl. 03-022010. Pkl. 09.00-11.00).

Dalam kesempatan yang berbeda, Abdul Hadi sebagai Ketua Sekolah Tinggi Agama Islam Negeri (STAIN) Kudus mengatakan hal yang lain tentang bawahannya:

"Saya yakin bahwa bapak-bapak pimpinan di bawah saya, adalah orangorang pintar yang sudah sangat paham dengan tugas dan fungsi (tupoksi) nya masing-masing, sesuai dengan tanggung jawab yang mereka pikul. Kalau mereka tidak ada keluhan, berarti saya anggap semua berjalan sesuai koridornya. Dan terbukti, segala aktivitas di STAIN Kudus berjalan dengan baik-baik saja" (hasil wawancara dengan Ketua STAIN Kudus tgl. 18-03-2010, Pkl. 11.00-12.30)

Di tempat lain, seorang dosen STAIN Kudus yang diduga berpihak pada kubu oposisi berkesimpulan bahwa kesan umum yang dirasakan oleh peserta rapat atas pidato ketua diidentikkan dengan ceramah umum 'tausiyah'. Pembicaraan kerap kali tidak fokus dengan tema yang dibahas dan juga terlalu penuh dengan dalil-dalil (hasil wawancara dengan salah seorang dosen STAIN Kudus tgl. 14-02-2010. Pkl. 12.00-13.00).

Konflik internal pimpinan dan kepemimpinan di STAIN Kudus itu mengerucut pada konflik antara ketua dengan pembantu ketua I. Masing-masing kubu merasa dirinya benar. Akan tetapi, dampak yang tidak bisa dihindari adalah penghormatan dosen terhadap pimpinan STAIN Kudus menjadi menurun. Secara umum, dosen memandang bahwa ketua bisa kalah wibawa oleh Pembantu Ketua I. Hal ini tentu berdampak pada kinerja dosen. Para dosen menjadi nampak kurang memiliki spirit dalam bekerja dan menghasilkan karya yang maksimal. Saat pimpinan mengundang rapat, para dosen sudah merasa pesimis terlebih dahulu, karena dalam pikiran mereka pimpinan hanya akan mendoktrin dan menginstruksikan tanpa diberi kesempatan untuk berdialog, saling memberikan masukan dan saling mengkritisi.

Sistem pengawasan yang dilakukan pimpinan dirasakan oleh sebagian dosen tidak menyentuh kinerja dosen sepenuhnya karena pimpinan terkesan membuat jarak terutama dengan kelompok di luar kelompoknya. Dampaknya, ada karyawan yang memutuskan untuk mencari tempat kerja yang baru. Ia merasa bahwa lingkungan kerja yang dibangun di STAIN Kudus sudah tidak sehat lagi. Tidak ada hubungan emosional yang cair, netral dan menenteramkan di antara atasan dengan bawahan/karyawan. Karyawan senantiasa diliputi perasaan takut dan cemas ketika ia tidak manut (tunduk taat dan patuh) pada pimpinan. Abdul Hadi, selaku Ketua STAIN mengatakan hal yang berbeda: 
"Secara umum, STAIN Kudus saat ini cukup baik, meskipun terkadang saya kecewa dengan beberapa teman dosen yang tidak khusyu' dengan dunia akademisnya tapi malah sibuk berpolitik, memprovokasi teman dosen yang lain sehingga suasana kampus menjadi tidak kondusif. Namun secara umum, dosen telah menunaikan tugasnya dengan baik. Mereka merasa harus bertanggungjawab karena mereka merasa bahwa dengan adanya tunjangan profesi dosen, mereka merasa tertantang untuk membuktikan bahwa kepada pimpinan bahwa mereka bekerja sesuai dengan aturan" (hasil wawancara dengan ketua STAIN Kudus tgl. 10-012010, Pkl. 08.00-09.00).

Perang urat syaraf ( $p$ sy-war) antara Ketua STAIN Kudus dengan Pembantu Ketua I semakin meruncing. Pada tempat yang terpisah, Pembantu Ketua I seolah menepis pengakuan Ketua STAIN dengan mengatakan:

"Terkadang keputusan yang ditetapkan pimpinan (ketua) tidak ada artinya, karena instruksi/perintah yang diberikannya seringkali masih bersifat global. Di samping itu pengawasan dari pimpinan tidak berfungsi dan tidak berjalan dengan baik. Perintah-perintah yang diberikan hanya sebatas instruksi spontan. Sejauh mana instruksi itu dilaksanakan, pimpinan tidak melakukan pemantauan yang jelas dan berkelanjutan" (hasil wawancara dengan Pembantu Ketua I STAI Kudus tgl. 03-02-2010, Pkl. 09.00-11.00).

Ketua/pucuk pimpinan (STAIN) Kudus, Abdul Hadi, merefleksikan sikap para pembantu/jajarannya dengan mengatakan:

"Saya yakin bahwa bapak-bapak pimpinan di bawah saya, adalah orangorang pintar yang sudah sangat paham dengan tugas dan fungsi (Tupoksi) nya masing-masing, mengerti segenap tanggung jawab yang mereka pikul. Kemudian, kalau dari mereka tidak ada keluhan, berarti saya anggap semua berjalan sesuai aturan. Berarti, selama ini, aktifitas di STAIN Kudus berjalan dengan baik-baik saja" (hasil wawancara dengan Ketua STAIN Kudus tgl. 18-03-2010, Pkl. 11.00-12.30).

Dalam pandangan Ketua I tidak demikian. Ia menjelaskan:

"Mestinya tidak semua kegiatan ke/di luar harus dilakukan oleh ketua atau harus dihadiri sendiri oleh beliau. Di sini berarti tidak ada fungsi pendelegasian dalam kepemimpinan STAIN Kudus" (hasil wawancara dengan Puket I. 03-02-2010. Pkl. 09.00-11.00).

Dari dokumentasi perjalanan dinas ke luar kota, tercatat frekuensi kepergian ketua terlalu sering dibanding pimpinan lain di bawahnya (Dok. Bagian Kepegawaian STAIN Kudus tahun 2010), sehingga Pembantu Ketua I menganggap ketua kurang fokus menyelesaikan persoalan-persoalan di dalam kampusnya sendiri. Perilaku kepemimpinan seperti ini, sangat berdampak pada cara pandang dosen. Berhubungan dengan keadaan ini, salah seorang dosen berkomentar:

"Ada dan tidak adanya ketua, terkadang sama saja, perhatian beliau terhadap apa yang kita kerjakan tetap saja kurang. Kalau ketua sering 
meninggalkan lembaga dengan alasan-alasan yang tidak jelas, tentunya kami juga bisa melakukan hal yang sama. Sekarang coba lihat saja, dalam satu bulan ini tidak pernah ada rapat/pertemuan dosen. Lantas bagaimana beliau bisa menilai kinerja kami ?" (hasil wawancara dengan dosen tgl. 2403-2010, Pkl. 08.00-09.00).

Dengan nada yang agak memprovokasi, Pembantu Ketua I menanggapi:

"Seyogianya para dosen tidak merasa cepat puas, dengan apa yang telah dicapainya saat ini (meraih ijazah S2 atau S3). Para dosen harus senantiasa mempunyai penampilan kerja yang menunjukkan bahwa ia mempunyai pengetahuan, keterampilan dan berpikir secara kritis dan rasional. Dosen yang baik bukan hanya dosen yang pandai berteori tentang ilmunya saja. Mestinya seorang dosen harus memiliki motivasi tinggi dan berani mengungkapkan aspirasinya untuk mengubah apa-apa yang dihadapannya perlu diubah" (Wawancara dengan Pembantu Ketua I 03-02-2010. Pkl. 09.00-11.00).

\section{Analisis}

Dalam bingkai teori Kate, Macobi dan Morese (1950), kondisi di atas menunjukkan bahwa kepemimpinan transaksional memiliki kecenderungan selalu berorientasi kepada penguatan hubungan antarpribadi dan pemenuhan kebutuhan bawahan. Cirinya pimpinan banyak; 1) mendelegasikan keputusan kepada bawahan; 2) membantu bawahan untuk memenuhi kebutuhan yang terkait langsung atau tidak dengan pribadinya; 3) berupaya menciptakan lingkungan kerja yang menyenangkan bahkan cenderung hedonis, 4) senang memperhatikan kemajuan pengikutnya. Blake dan Mouton memasukkan unsur perhatian pemimpin pada pola kepemimpinan transaksional ini sebagai pola yang bingkai manajerialnya senantiasa berupaya mempedulikan orang lain atau bawahan (Robin, 1996: 12). Kepedualian terhadap bawahan belum tentu mencerminkan sepenuhnya kepedulian pimpinan terhadap visi dan misi organisasi. Yulk (1998: 3) mengatakan:

"Most definitions of leadership reflect the assumption that it involves a process whereby intentional influence is exerted by one person over other people to guide, structure and facilitate activities and relationships in a group or organization".

"Kebanyakan definisi kepemimpinan mencerminkan asumsi bahwa kepemimpinan itu melibatkan suatu proses di mana pengaruh sengaja digunakan oleh seseorang pada orang lain untuk memandu, menyusun dan memudahkan aktivitas dan hubungan dalam suatu kelompok atau organisasi".

Yulk menunjukkan bahwa kepedulian/keberpihakan yang berlebihan dari pimpinan kepada kelompok tertentu bisa dimaksudkan sebagai upaya memperkokoh pengaruh dirinya agar ia lebih lama berkuasa. Ia pun menegaskan bahwa, the leader is the one who succeeds in getting others to follow him or her (pemimpin adalah seseorang yang bisa membuat orang lain mengikutinya) (Yulk, 1998: 3). 
Jika dikelola dengan baik, pola kepemimpinan transaksional dapat berdampak pada peningkatan produktivitas kelompok yang dia bela. Ia mengidentifikasi bahwa jika pola kepemimpinan semacam ini (transaksional) dilaksanakan secara luas dalam suatu organisasi, maka akan berdampak pada bangkitnya perasaan karyawan, meningkatnya rasa saling percaya, terbukanya ruang komunikasi dan melimpahnya rasa hormat dari seluruh bawahan yang terdapat dalam suatu organisasi terhadap atasan (Robin, 1996: 10 dan Gibson et. al., 1992: 18).

Dalam perspektif teologi Islam, seorang pemimpin yang baik harus kuat dan berani memegang amanah kepemimpinannya, jika tidak maka ia berdosa dan masuk neraka. Firman Allah QS. Al-Baqarah [2]: 30-34 (Junus, 2000: 6-7) menyebutkan bahwa pada dasarnya Allah SWT menjadikan manusia sebagai pemimpin/khalifah di muka bumi untuk mengemban amanah kekhalifahannya yaitu tidak membuat bencana dan menunjukkan wujud keutamaan (pengetahuan) yang dimiliki anak Adam (manusia). Pada ayat 34 surat 2 pun disebutkan bahwa akhirnya malaikat pun bersujud kepada sang pemimpin 'khalifah'. Ini menunjukkan betapa mulianya derajat orang-orang yang memimpin dan mempunyai ilmu. Dalam QS. Al-Ahzab [33]: 72 (Junus, 2000: 386), Allah SWT berfirman bahwa sesungguhnya Allah telah menawarkan tugas-tugas keagamaan kepada langit, bumi dan gunung-gunung namun mereka menolak memikul amanat yang diberikan Allah karena hawatir akan mengkhianatinya. Kemudian amanat tersebut diberikan kepada manusia dan manusia menerimanya. Konsekuensinya, barang siapa menjalankannya dengan baik maka akan mendapat pahala surga. Sebaliknya, barang siapa yang mengkhianatinya akan disiksa dan dimasukkan ke dalam api neraka.

Manusia, walaupun secara fisik sangat kecil dibanding dengan langit, bumi dan gunung-gunung namun bersedia menerima amanat Allah SWT tersebut karena ilmu dan amalnya. Hanya ilmu dan amal itu sering bertukar balik dengan nafsu dan syahwat. Jika manusia sebagai khalifah ini lebih mengikuti keduanya Allah mensifati mereka sebagai orang zalim. Dalam satu hadis, Nabi SAW memperingatkan bahwa, "Tiada hari seorang hamba yang dijadikan Allah sebagai pemimpin rakyat (bawahannya) namun tidak memedulikan perkara mereka, melainkan ia tidak akan mencium aroma surga" (HR. Bukhari dan Muslim dalam Abdul Baqi, 2011: 105). Logika teologis inilah yang tertanam dalam benak kubu oposisi. Sehingga mereka sebagai (Muslim) oposan merasa tidak perlu lagi loyal, tunduk, patuh dan taat kepada ketua mereka. Hal ini berdampak pada lalainya sebagian dosen, terutama kubu oposisi dalam memperhatikan kualitas kinerjanya sendiri.

Dalam tinjauan filsafat manajemen, Plato mengatakan bahwa manusia secara kodrati memiliki tiga komponen psikologis yang saling berkaitan antara yang satu dengan lainnya yaitu pikiran 'rational part', kehendak 'the courageous part or spirited part' dan nafsu 'the appetitive part' (Copleston, 1993: 208). Dorongan mengeluarkan pendapat dan pikiran memerlukan saluran. Agar kebutuhan penyaluran gagasan semua sivitas akademika STAIN Kudus berlangsung, pola 
pimpinan kharismatik mestinya mengindahkan pula karakteristik kepemimpinan efektif. Razik dan Swanson (1995: 39) mengatakan:

"Scholarly attempts to analyze leadership have resulted in many diverse definitions, theories, model and applications; however there is no general consensus of what constitutes leadership or effective leadership within organizations. Apparently, most scholars would agree with Burns' (1978) conclusion that leadership is one of the most observed and least understood phenomena on earth".

"Beberapa sarjana berupaya menganalisis kepemimpinan yang telah banyak menghasilkan aneka ragam definisi, teori, model dan penerapan; meskipun demikian tidak ada kesepakatan umum tentang hal yang membangun kepemimpinan atau kepemimpinan efektif dalam sebuah organisasi. Akhirnya, mayoritas sarjana sepakat dengan simpulan yang dibuat oleh Burn's (1978) bahwa kepemimpinan adalah satu dari sekian banyak fenomena yang ada di muka bumi yang setidaknya teramati dan dapat dimengerti".

Kepemimpinan efektif ternyata berakar pada fenomena yang tidak tunggal. Kepemimpinan efektif memasukkan salah satunya kategori 'relasi', sebagai sesuatu yang keberadaannya terhubung dengan hal lain, termasuk lingkungan sosial dan budaya suatu kampus. Relasi tersebut juga bisa mengarah kepada pekerjaan itu sendiri sehingga ia mampu menampilkan kualitas kinerja personil yang sebenarnya. Stodgill \& Coons (1957) menguatkan bahwa pemimpin yang mengorientasikan kepemimpinannya untuk pekerjaan dapat melahirkan pencapaian tujuan (kepedulian) kerja yang maksimal dan karena mampu menentukan serta mengarahkan kinerja karyawan (Robin, 1996: 12). Namun demikian, teori Michigan mengingatkan bahwa pimpinan yang visinya berorientasi pada struktur pekerjaan memiliki kelemahan yaitu kurang memperhatikan kebutuhan orang, pengawasan cenderung ketat dan lebih banyak menggunakan prosedur khusus dan cenderung mengesahkan mekanisme paksaan, imbalan, maupun kekuasaan secara masif. Dampaknya pun bisa kontraproduktif dengan tujuan organisasi yakni produktivitas organisasi dan kepuasan anggota menjadi rendah (Robin, 1996: 10; dan Gibson et. al., 1992: 18).

Kekhawatiran dari dampak teori Michigan terbukti. Sebagai perguruan tinggi negeri, alokasi dana dari pemerintah pusat sebetulnya sudah mencukupi. Menurut Pembantu Ketua II (Bidang Keuangan dan Kepegawaian) Choiron;

"Meningkatnya jumlah mahasiswa STAIN Kudus dari tahun ke tahun, membuat alokasi dana kita dari Kemenag (Kementerian Agama RI) juga mengalami peningkatan yang cukup signifikan. Oleh karena itu, sebagai pimpinan, kami kini lebih leluasa untuk menyusun program pengembangan kelembagaan dan meningkatkan profesionalisme dosen. Setiap tahun kami mengalokasikan bantuan untuk mereka yang melanjutkan studi ke jenjang S3. Kami juga mengalokasikan dana bantuan penelitian untuk semua dosen tetap STAIN Kudus, serta mengadakan 
kegiatan-kegiatan lain seperti seminar, workshop dan pelatihan" (hasil wawancara dengan pembantu ketua II. 15-03-2010. Pkl. 10.00-11.00).

Dukungan dana yang ada mestinya mendorong pimpinan lebih leluasa dalam menyusun program dan rencana strategis lembaga, termasuk programprogram yang diorientasikan pada peningkatan kinerja dosen seperti mengadakan pendidikan dan pelatihan yang bertujuan meningkatkan kualitas akademik, memperbanyak dana penelitian dan penulisan buku daras, maupun memberikan bantuan studi lanjut kepada dosen.

Sertifikasi dosen pun dapat ikut meringankan beban pimpinan dan lembaga dalam mengontrol kinerja dosen. Sebab seiring dengan adanya tunjangan sertifikasi dan tunjangan kehormatan guru besar, kehidupan ekonomi dosen pun tidak lagi memprihatinkan. Sebagai dosen profesional dengan sejumlah penghargaan materi yang cukup besar dari pemerintah, mereka lebih fokus dalam meningkatkan kualitas dan produktivitas kerjanya. Pedoman penilaian Beban Kerja Dosen (BKD) pun sudah terperikan dengan jelas, namun pelaksanaannya belum secara jujur dan bertanggungjawab dilakukan sesuai dengan prosedur yang ada sebab mekanisme penilaian kinerja di tingkat program studi belum berjalan dengan tertib. Semuanya masih bersifat instruksional yang akan dikerjakan oleh dosen ketika keadaan sudah mendesak. Ukuran-ukuran kinerja baik secara kualitatif maupun kuantitatif dalam rangka pengamalan kompetensi dosen belum dilaksanakan secara optimal. Produk-produk yang dihasilkan dosen seperti: karya ilmiah (penelitian, modul, buku dan jurnal) maupun prosentase kehadiran dosen di dalam kelas secara kuantitatif masih rendah. Kejujuran, inisiatif, sikap, kerja sama, keandalan, wawasan dan pengetahuan tentang pekerjaan serta tanggung jawab pengembangan keilmuan yang dituntut sesuai dengan kompetensinya tidak terdeteksi dan terdokumentasikan dengan baik.

Akreditasi program studi yang rata-rata B mestinya dapat mencitrakan Sekolah Tinggi Agama Islam Negeri (STAIN) Kudus sebagai kampus yang baik. Sarana dan prasarana sebagian sudah dipenuhi oleh pemerintah pusat melalui dana DIPA (Daftar Isian Proyek Penyelenggaraan Akademik) Kementerian Agama Republik Indonesia dalam setiap tahunnya. Sarana dan prasarana penunjang perkuliahan pun, seperti ruang kelas, alat tulis kantor, LCD/proyektor dan laboratorium pun relatif sudah terpenuhi. Salah seorang dosen berkomentar:

"Meskipun kami belum cukup puas dengan fasilitas-fasilitas yang disediakan untuk keperluan perkuliahan, tapi sebagai sebuah terobosan baru dan inovatif, kami sangat menghargai jerih payah para pimpinan STAIN Kudus. Kami sangat terbantu dengan penambahan beberapa fasilitas, seperti ruangan yang ber-AC, ada in focus (LCD) dan laboratorium yang cukup memadai. Semoga kami bisa memaksimalkan segala fasilitas itu, demi berjalan dan meningatnya aktivitas akademik di lembaga yang 
kami cintai ini" (hasil wawancara dengan dosen tgl. 24-03-2010, Pkl. 08.00-09.00).

Pemanfaatan atas sejumlah potensi fisik untuk peningkatan kinerja dosen STAIN Kudus masih belum tergarap secara maksimal. Keadaan lingkungan politik kampus yang belum sepenuhnya netral, menyebabkan pola kepemimpinan kharismatik yang dijalankan ketua STAIN Kudus tidak berjalan dengan efektif. Kecenderungan politis dosen yang terpilah menjadi dua kubu justru semakin membesar. Dua kubu yang berseteru, yang pada awalnya hanya melibatkan dosen secara terbatas, kini semakin meluas dan menguat membentuk dua kelompok politik besar. Kebijakan-kebijakan pimpinan STAIN Kudus justru nampak semakin bergantung pada kebijakan-kebijakan dari Kemenag Pusat. Pola kepemimpinan kharismatik yang dijalankan pimpinan justru lebih menampilkan sosok kepemimpinan yang semakin tidak efektif. Pimpinan, menampakkan perilaku yang berorientasi kepada pengembangan dosen seperti menghargai pelbagai upaya hasil eksperimen, gagasan baru dan perubahan (Robin, 1996: 13) justru dosen sebagai bawahan semakin merasa tidak terpuaskan dan hanya dipandang sebelah mata oleh pimpinan. Dengan demikian, pola kepemimpinan kharismatik yang dijalankan Ketua STAIN Kudus cenderung berubah menjadi kepemimpinan situasional. Hal ini ditandai dengan 1) meningkatnya kadar bimbingan dan arahan yang diberikan oleh pimpinan, 2) menguatkan kadar dukungan sosioemosional kelompok tertentu yang disediakan pimpinan dan (3) menurunnya tingkat kesiapan (kematangan) yang diperlihatkan dosen pada umumnya dalam menjalankan tugas yang dibebankan organisasi/lembaga (analisis berdasarkan teori Hersey dan Blancard 1982: 178).

Kepemimpinan di STAIN Kudus, merujuk pada pendapat Sanusi (1998: 20) belum mencerminkan suatu kenyataan bahwa ia mempunyai kekuatan dan keberanian dalam menyatakan kemampuan mental, yang didukung oleh unsurunsur penting sebagai ways and means yaitu: 1) kemampuan menciptakan, menjelaskan dan menawarkan gagasan-gagasan baru dalam tema yang menarik, kreatif, terbuka untuk diuji, lebih unggul dalam persaingan atau tawar-menawar dengan pihak lain, terutama bawahannya; 2) kemampuan argumentatif dan mempertahankan pendirian secara etis-rasional sehingga pihak lain termotivasi untuk merundingkan dan mempertimbangkan hingga akhirnya menerima pilihan yang diturunkan dari gagasan tadi; 3) kemampuan mempengaruhi pihak lain dengan menggunakan metode yang paling sesuai sehingga semua pihak bekerja sama dan dalam satu kesatuan organisatoris, mentaati arahan dan koordinasinya; 4) kemampuan mengendalikan bentuk-bentuk kerja sama yang semakin stabil dan prosesnya makin produktif melalui pemilihan personil yang kokoh.

Dalam telaah Bryman (1992: 21), model kepemimpinan Sanusi sepadan dengan model kepemimpinan transformasional. Sarros dan Butchatsky menyebutnya sebagai pemimpin penerobos 'breakthrough leadership'. Pemimpin penerobos adalah pemimpin yang mampu membawa perubahan-perubahan besar baik terhadap individu maupun organisasi dengan jalan memperbaiki 
kembali (reinvent) karakter diri individu-individu dalam organisasi maupun keseluruahn organisasi, menciptakan inovasi, meninjau kembali struktur, memperbaiki proses dan membangun kembali nilai-nilai organisasi agar lebih baik dan lebih relevan. Hal ini dapat dilakukan dengan cara-cara yang menarik dan menantang bagi semua pihak yang terlibat dan mencoba untuk merealisasikan tujuan-tujuan organisasi yang selama ini dianggap tidak mungkin dilaksanakan. Pemimpin penerobos mempunyai pemikiran yang metanoiac 'menembus kedalaman pikiran' dan dengan bekal pemikiran ini sang pemimpin mampu menciptakan pergesaran paradigma untuk mengembangkan praktikpraktik organisasi agar lebih maju dan baru (Bryman, 1992: 21).

Dalam perpektif teologi Islam, Nabi Muhammad SAW adalah sosok pemimpin yang tidak banyak menyuruh dan melarang tetapi lebih banyak menerapkan model suri teladan. Dalam QS. Al-Ahzab [33]: 21 disebutkan: "Sesunggubnya telah ada pada (diri) Rasulullab SAW itu suri teladan yang baik bagimu (yaitu) bagi orang yang mengharap (rahmat) Allah SWT dan (kedatangan) hari kiamat dan dia banyak menyebut Allah SWT" (Digital Qur'an Versi 3.2. Juz 21). Nabi Muhammad SAW lebih mengedepankan aksi 'action' daripada instruksi/perintah. Nabi Muhammad SAW menghindari menggunakan metode nasihat karena banyak nasihat itu tidak disukai Allah SWT (QS. Ash-Shaffat [61]: 2-3; dalam digital Qur'an Versi 3.2. Juz 28).

Rasulullah SAW adalah pemimpin yang holistic, accepted dan proven. Kepemimpinan beliau melingkupi bidang: bisnis, rumah tangga, masyarakat, politik, pendidikan, hukum, pertahanan dan negara. Kepemimpinan beliau pun accepted 'diterima' karena diakui lebih dari 1,3 milyar manusia dan proven (terbukti) karena lebih dari 15 abad masih relevan untuk diterapkan (Antonio, 2009: 6-7). Antonio membandingkan kepemimpinan Muhammad dengan Characteristic of $V$ alues-Based Leaders dari Bennis dan ternyata menempati semua kriteria yang digagas oleh Bennis. Muhammad adalah seorang yang visioner, berkemauan kuat, memiliki integritas, amanah, serba ingin tahu dan berani. Dalam Megaskills of Leadership dari Nanus, Muhammad pun merupakan pimpinan yang berpandangan jauh ke depan, menguasai perubahan, mampu mendesain organisasi, seorang pembelajar yang antisipatoris, berinisiatif tinggi, terampil menginterdependensi dan memiliki standar integritas yang tinggi (Antonio, 2009: 26-27).

\section{SIMPULAN}

Pemimpin dan kepemimpinan di STAIN Kudus ternyata belum mencerminkan kepemimpinan Rasul Muhammad SAW yang komprehensif dan memenuhi seluruh kriteria kepemimpinan yang ada saat ini. Padahal bisa jadi, kedua pimpinan sangat memahami dan meyakini kebenaran ajaran Rasul Muhammad. Ada beberapa kendala yang menyulitkan pimpinan STAIN Kudus untuk menerapkan baik pola kepemimpinan transformasional Bryman, interdependensi, suri teladan dan orientasi aksi dari Rasul Muhammad SAW 
yaitu secara eksternal intervensi Kemenag Pusat terlalu kuat dan secara internal ada konflik kepemimpinan yang berkepanjangan antara Ketua dengan Pembantu Ketua I STAIN Kudus. Konflik internal tersebut merupakan dampak dari konflik historis antara pendukung Masyharuddin dengan penentangnya dalam pemilihan langsung Ketua STAIN Kudus tahun 2005. Konflik internal tersebut justru semakin tajam karena Ketua STAIN terpilih, Abdul Hadi, bukan asli berasal dari STAIN Kudus. Konflik internal yang berkepanjangan ini berdampak pada kinerja dosen STAIN Kudus. Secara umum, 'ideologi-politik' dosen STAIN Kudus terbagi ke dalam dua kubu yaitu kubu yang mendukung Ketua dan kubu yang mendukung Pembantu Ketua I, Kahar Utsman. Kedua kubu tersebut pada dasarnya merupakan tangan panjang dari kubu pendukung Masyharuddin dan penentangnya, namun sudah berubah bentuk. Pendukung Masyharuddin dan berarti juga pendukung Abdul Hadi didominasi oleh kaum muda yang secara ideologi-akademis kuat namun secara finansial lemah. Pendukung Kahar Utsman didukung oleh dosen senior yang secara ideologiakademis lemah namun secara finansial mapan. Dampak konflik internal kepemimpinan di STAIN Kudus terhadap kinerja dosen dapat terlihat pada menurunnya frekuensi tatap muka perkuliahan, kurang bersemangatnya dosen dalam mengembangkan karir akademiknya dan tingkat partisipasi yang rendah dari dosen dalam mengikuti program-program peningkatan akademik yang diselenggarakan oleh pimpinan STAIN Kudus. Berarti, pemimpin dan kepemimpinan sebagai variabel organisasi pendidikan (sebagai variabel eksternal anggota organisasi) merupakan variabel penting yang dapat mempengaruhi kinerja individu (personil pendidik). Faktor pimpinan sangat menentukan tingkat kecenderungan pimpinan dalam memberikan peluang-peluang pekerjaan tambahan (proyek) yang dapat menambah penghasilan anggota organisasi. Pimpinan STAIN Kudus memiliki kewenangan khusus dalam mengatur, memilih dan menentukan besaran distribusi proyek dan kegiatan lembaga serta menunjuk kepada siapa proyek, kegiatan, program itu akan diberikan. Sangat masuk akal jika pimpinan lebih memprioritaskan peluang tersebut kepada bawahan yang mendukungnya. Berarti sangat masuk akal pula jika bawahan yang tidak kebagian peluang tersebut berupaya menentang kebijakan pimpinannya.

\section{DAFTAR PUSTAKA}

Abdul Baqi, Fuad, Muhammad. 2011. Al-Lu'lu’ Wal Marjan. Jakarta: Ummul Qura.

Antonio, M. S. 2009. Mubammad SAW: The Super Leader Super Manager. Jakarta: ProLM Centre \& Tazkia Publishing.

Bryman, A. 1992. Charisma and Leadership in Organization. London: Sage.

Copleston, Frederick, S.J. 1993. A History of Philosophy Volume I, New York: Imge Books.

Data Kepegawaian STAIN Kudus. 2012.

Dokumen Lembaga PPMP STAIN Kudus. 2010. 
Dokumen Bagian Kepegawaian STAIN Kudus. 2010.

Galamedia dalam http://akatelsp.ac.id/2009/01/09)

Gibson, F. W. 1992. Stress, Babble, and the Utilization of the Leader's Intellectual Abilities. Leadership Quarterly.

Hersey, P. dan Blanchard, K. H. 1982. Management of Organizational Behavior: Utilizing Human Resources, diterjemahkan oleh: Agus Dharma, Manajemen Perilaku Organisasi: Pendayagunaan Sumber Daya Manusia. Jakarta: Penerbit Erlangga.

Hesselbein, F., Goldsmith, Marshall \& Beckhard, Richard (eds). 1996. The Leader of The Future. New York: Drucker foundation.

Jillson, Calvin and Wilson, Rick K. 1994. Congressional Dynamics. Stanford: Stanford University Press.

Junus, Mahmud. 2000. Tarjamah Al Qurän Al Karim. Bandung: Al-Ma'arif.

Kuncoro, E. A. 2008. Daya Saing (Competitiveness) Perguruan Tinggi Swasta (Analisis Faktor-Faktor yang Berpengaruh secara Dominan terhadap Daya Saing PT Swasta di DKI Jakarta), Disertasi Sekolah Pascasarjana UPI Banding, Tidak diterbitkan.

Miles, M. B and Huberman, A. M. 1994. Qualitative Data Analysis. Second Edition, London: Sage.

Muhaimin. 2002. Paradigma Pendidikan Islam: Upaya mengefektifkean Pendidikan Agama Islam di Sekolah. Bandung: PT. Remaja Rosdakarya.

Razik, T. A. and Swanson, A. D. 1995. Fundamental Concepts of Educational Leadership and Management. New Jersey: Englewood Cliffs.

Robbins, S. P. 1996. Organizational Behavior. Mexico: Prentice Hall.

Sanusi, A. 1998. Pendidikan Alternatif. Bandung: Program Pascasarjana dan PT Grafindo Media Pratama.

Sutermeister, R. A. 1976. People and Productivity. New York: McGraw-Hill Book Company.

Usman, H. 2006. Manajemen Teori, Praktik dan Riset Pendidikan. Jakarta: Bumi Aksara.

Yukl, G. 1998. Leadership in Organizations. New Jersey: Prentice Hall.

http://www.webometrics.info 